\title{
Ecology, environmentalism and green religion
}

\author{
by J.P. (Hamish) Kimmins
}

Forests offer diverse values to society, including timber, aesthetics, wildlife and biodiversity values, employment and wealth. Forests must be managed to provide the balance of values at the landscape level that the prevailing society deems to be consistent with the basic concept of sustainable development: to satisfy the needs and aspirations of present generations of humans without compromising the ability of future generations to satisfy their needs and aspirations.

Management of forests to satisfy the requirements of sustainability will not be successful if based solely on the science of ecology, because this science cannot tell foresters what their goals should be. It will also fail if it is based solely on green religion, because this frequently ignores the ecological requirements of many of the living organisms in forest ecosystems, and the needs of the world's present human population, let alone the increase in human numbers that is expected within the next century.

Broadly-defined environmentalism should be the basis for managing and conserving the world's forests. This management should be based on the ecology of these forests, should address the multiple values they provide, and should respect current ethical standards concerning the environment. The foresters performing this management should be dedicated environmentalists (in the broad sense). Unless the forestry profession becomes the leader in forest environmentalism, there is a significant risk that forestry in the future will be based largely on green religion.

\section{Introduction}

Forestry around the world is facing unprecedented challenges. A public that was previously too uninformed, too preoccupied with providing the basic necessities for life, or simply too uninterested in environmental issues, has been awakened to the threats to the world environment in general, and to forests in particular. In many cases, the aroused public is challenging the way forests have been, and are being, managed, and in some cases mismanaged. In forestry, business can definitely not continue "as usual".

If this "environmental revolution" had not occurred, there is little question that much of the world's tropical forest would eventually have been lost due to land use changes or degraded by non-sustainable harvesting methods, and that large areas of temperate and northern/high elevation forest would have been subject to continued harvesting at rates and by methods that some people believe to be non-sustainable. Without the past decade of concern about how forests are managed, it is probable that much of the world's forest area would have been managed mainly to achieve timber production objectives, to the detriment of some of the other values of the forest.

Professor of Forest Ecology, Faculty of Forestry, University of British Columbia, Vancouver. Keynote address at Larch Conference, Whitefish, Montana, October 5-9, 1992.
Les forêts représentent différentes valeurs pour la société que ce soit sous forme de bois, de paysages, en terme de valeur faunique ou de biodiversité, d'emplois et de richesses. Les forêts doivent être aménagées afin de procurer un ensemble équilibré de valeurs au niveau du paysage tel que la société actuelle juge être logique avec le concept de base du développement durable; afin de satisfaire les besoins et les aspirations des générations présentes d'êtres humains sans comprometre les besoins et les aspirations des générations à venir.

L'aménagement des forêts dans le but de satisfaire les exigences de la durabilité ne connaîtra pas de succès s'il repose uniquement sur la science de l'écologie, parce que cette science ne peut indiquer aux forestiers ce que devraient être leurs objectifs. Il sera voué également à l'échec s'il repose uniquement sur les religions vertes, parce que celles-ci ignorent fréquemment les exigences écologiques de la plupart des organismes vivant au sein des écosystèmes forestiers, ainsi que les besoins de la population mondiale actuelle, sans parler de l'accroissement de la population humaine qui est prévue au cours du prochain siècle.

Un environmentalisme défini d'une manière globale devrait constituer la base de l'aménagement et de la conservation des forêts mondiales. Cet aménagement devrait s'appuyer sur l'écologie de ces forêts, tenir compte des multiples valeurs qu'elles contiennent, et respecter les normes actuelles d'éthique relativement à l'environnement. Les forestiers responsables de l'aménagement devraient être des environnementalistes convaincus (dans le sens large). A moins que les forestiers professionnels ne deviennent les leaders de l'environnementalisme forestier, nous courons un risque significatif que la foresterie soit fondée principalement sur une religion verte.
One consequence of the "environmental movement" of the 1980's and early 1990's has been a reexamination of how we manage forests and of the values for which they are managed. There is no doubt that this reexamination will result in many improvements in forest management and forest conservation. However, there are continuing threats to the world's forests. The combined pressures of population growth and poverty will result in a continuing loss of the forest resource in many countries, and continuing inadequate levels of management, especially in the tropical third world. In addition, well-intended efforts to conserve forests may fail, or even be counter productive, if they are not adequately based in the science of forest ecology and if they do not recognize existing social and economic realities.

Credit for the recent change in public attitudes towards the world's forests lies largely with the environmental movement. Although many foresters have expressed concern about the way in which forests have been harvested and managed, their message went largely unheard by governments and forest companies. Few scientists and academics participated in these issues; most were too preoccupied with reductionist research and the demands of their careers that they do narrowly-focused science; many were not interested in dealing with "real world" problems. It was rare for researchers to become involved in the broad social, environmental and resource issues that beset society, and those who 
did were frequently ignored by the forest industry and government forestry agencies. It has been a relatively small group of dedicated environmentalists, working largely through the media, who have wrought the change in public awareness of environmental issues that others failed to do. Society owes them a debt of gratitude. However, society will thank them much more if their contribution to the public consciousness-raising stage (the "political" phase) of conservation and improved resource management is matched by constructive contributions to the development and implementation of policies, regulations and resource management strategies that are successful in solving environmental problems and achieving both sustainable resources and a sustainable environment (the "implementation" phase of conservation).

If the environmental movement is only able to participate in the political phase of conservation, they will have played a very necessary but not a sufficient role in the overall conservation process. Unless environmentalists are able to make the transition, when the time is appropriate, from the strategies that are necessary for the political phase to the strategies that are effective in the implementation phase of conservation, the environmental movement will be much less successful in achieving its overall long-term objectives than it has been with its short-term objectives.

One of the threats to the success of the environmental movement is the current confusion between the roles of ecology, environmental belief systems ("green religion") and what I interpret to be environmentalism: an activity that has as its objective sustaining both the multiple values of the environment and the supply of resources for people from the environment. My objective in this paper is to review the contributions that ecology, environmentalism and green religion make to conservation and sustainable forest management, and to suggest that environmentalism, rather than ecology or green religion, provides the paradigm for sustainability.

The challenge to foresters today is to find methods of managing forests that will achieve both the social and environmental goals of society, and are consistent with the ecology of the species in the forest. They must also learn to communicate the scientific and social basis for their choice of sustainable systems of management to the concerned public.

The opportunities posed to foresters by the present level of environmental concern is to use this public pressure to persuade both governments and forest companies to adopt forest policies, regulations and practices that are consistent with good stewardship of the forest and which constitute sustainable management for multiple values.

\section{Ecology}

Ecology is a science. It provides no value judgments, though the understanding of ecosystems that ecology can provide may be a partial basis for them. Phrases such as "ecologically sound" forest harvesting or "ecologically destructive" forest management have no scientific basis and no information content outside of the context of society's prevailing value judgment system. Such terms imply that the science of ecology can tell us that one particular condition of a particular ecosystem is best: that it is better than all other possible conditions which that ecosystem might be in. Implicit in such statements is the idea that ecology, like Father Christmas, knows which forest management has been good and which has been bad. However, ecology cannot tell you if a clearcut is better or worse than a shelterwood, if a young forest is better or worse than an old growth stand, or whether low species diversity is better or worse than high species diversity. These questions can only be answered in the context of forest management objectives or society's prevailing preferences and value systems. Once these preferences and values have been established and agreed upon, ecology can help in the evaluation of whether the present ecosystem condition satisfies society's environmental and resource objectives, whether the effects of management on the form and functioning of ecosystems is consistent with the declared preferences and value systems, and, if not, how management might be altered to satisfy them. But it is society, not the science of ecology, that establishes the standards. Ecology merely describes, explains, provides a means of predicting future ecosystem conditions, and contributes to the development and implementation of sustainable management strategies.

Ecology had its origins in the middle of the last century. Beginning with the earlier concerns of Malthus about human population growth, and moving through the developing ideas of evolution, species diversity and genetics (Darwin and Mendel), it became increasingly apparent that the disciplinary sciences of biology, chemistry, physics and the earth sciences needed a complementary activity that could describe, explain and predict conditions and events in entire natural or managed ecosystems or landscapes. The genesis of ecology was encouraged by the failure of traditional scientific disciplines to provide a basis for sustainable agriculture and forestry, and to provide the understanding needed to predict and manage outbreaks of pests and diseases. Forest science and agricultural science had the same origins as ecology.

Ecology has not yet served society as well as it might have done. Established as a science dealing with entire ecological systems, it rapidly evolved into subdisciplines dealing with the ecology of individual organisms, with the distribution, abundance and change over time in groups of organisms of the same species (populations), and with complex mixtures of species (communities). Some ecologists maintained an interest in whole landscape units (ecosystems), but they tended to focus on individual functional processes of the entire system (e.g., energy dynamics and nutrient cycling), and not on the complex interactions of multi-species assemblages in ecosystems. Ecology began to lose sight of the central focus of the science: how ecosystems work and how they respond to disturbance.

In their attempts to become rigorous and scientifically respectable, ecologists increasingly adopted the reductionist research approach of the disciplinary sciences. Essential for the advance of our understanding of individual ecological processes, reductionism led many ecologists away from the natural complexity of ecosystems into the simplified, artificial realm of experimental science. The lack of appropriate methods and tools for studying whole, complex ecosystems, and the need to understand ecosystem processes in order to understand whole ecosystems, made this trend both inevitable and necessary. However, for a long time it prevented ecology from making major advances in our understanding of, and ability to predict, whole ecosystems, and greatly reduced the contribution of ecology to solving the emerging environmental and social problems associated with over-use, misuse 
and abuse of forest ecosystems. Reductionism led many ecologists to focus on the individual pieces of the forest jigsaw puzzle rather than focusing on interpreting the assembled picture and how it changes over time in the face of periodic disturbance, whether natural or human-caused.

It is not surprising, therefore, that the science of ecology failed to become the "knight in shining armor" that rescued the environment from its "attackers": us, the human species. Unless it is synthesized and integrated to the level of the ecosystem, much of the current body of ecological knowledge provides little basis for predicting whole ecosystem response to management or natural disturbance; the knowledge was created at the wrong temporal, spatial and complexity scales for this purpose. But this is not the main problem. No matter how good our ecological knowledge, it cannot, on its own, provide a basis for deciding what is good and what is bad resource management. That must be decided by society.

\section{Green Religion}

Religion can be variously defined as: 1 . any system of belief or worship, often involving a code of ethics; 2 . any system of beliefs, practices and ethical values; or 3 . belief in a divine or superhuman power. The emphasis is on belief, which in turn implies faith that something is true. Religion is the body of doctrine held by people who profess a faith. Faith is unquestioning belief. It does not require evidence or facts. ${ }^{1}$

People who think of themselves as environmentalists form a remarkably heterogeneous group: from young school children to elderly seniors, from "alternative life-stylers" to "conservative" business people and professionals, and from scientists and academics to applied engineers. "Environmentalists" include concerned citizens who believe in harvesting the things people need from their environment and in managing ecosystems to achieve particular ecosystem conditions and/or resource values, but who insist that this be done sustainably and in a way that respects many different resource values. Such people generally base their opinions on the best available information, both from the bio-physical and social sciences. There are also people who call themselves environmentalists for whom environmentalism has become a belief system. They have embraced "green religion" and they have absolute faith in its teachings.

Green religion is characterized by many profound beliefs about forest ecosystems, including such ideas as:

- Clearcutting always destroys forest ecosystems.

- Monoculture (single tree species) forests are unnatural and are inherently unstable and unsustainable.

- Plantation forestry always reduces genetic diversity.

- Forests established by planting seedlings (i.e., plantations) are not forest ecosystems.

- Natural disturbance (e.g., fire, windthrow) is the "rebirthing" of nature, whereas management-caused disturbance such as clearcutting is the "crucifixion" of nature.

- High biological diversity is good; low diversity is bad.

- Forests cannot be harvested and sustained.

- The only timber harvesting that should be permitted anywhere is individual tree selection.

\footnotetext{
'Definitions from Webster's New Twentieth Century Dictionary of the
} English Language Unabridged, 2nd ed. 1972. Collins-World Publ. Co.
- The present condition of a mature or old-growth forest is the correct condition for that forest ecosystem and should not be changed.

- All forests should be grown on long rotations of at least several centuries.

- Old growth forests should not be logged.

- Herbicides destroy forest ecosystems and poison wildlife and people.

- There are no forests that have been harvested sustainably more than 2 or 3 times. After this, there is progressive ecosystem breakdown.

These ideas are often held passionately, irrespective of whether they agree with our current scientific understanding of what ecosystems are and how they work (which is certainly incomplete and sometimes in error), or whether practical experience around the world suggests that these beliefs are only justified under certain circumstances, or only in particular forest ecosystems, or are entirely unjustified.

Green religion cannot be considered to be environmentalism, because any activity that systematically ignores available knowledge about the scientific and social dimensions of environmental problems poses a major risk of failing to arrive at solutions to these environmental problems. Belief systems that ignore our current understanding of environmental issues are not consistent with the aims and objectives of environmentalism. People who embrace green religion rather than environmentalism must be considered to be a separate and distinct group in society.

\section{Environmentalism}

Environmentalism is a movement that had its origins in the writings of people like Thoreau and Leopold: individuals who saw many values in natural, unmanaged ecosystems, and who believed in the need to respect nature. Environmentalists are people concerned about, and who actively work to solve, environmental problems. They are people who advocate the control of human population growth, and who promote conservation and sustainable management of the environment and of renewable resources. Environmentalism reflects the desire to conserve and sustain specific values and conditions in the environment in the face of increasing pressures on, and demands from, that environment by people.

For nearly a century, the slowly developing science of ecology has failed to provide answers to issues such as pollution, over-exploitation of resources and unregulated development. In part, this was the result of the small number of ecologists, the lack of resources available to them, and the lack of recognition of this new science of ecosystems. It was also, as noted earlier, partly because ecology was busy getting lost in scientific reductionism. A third reason for the failure of ecology to solve these issues is because they are only partly scientific in nature. In many cases they are more social and political than scientific problems, and their solutions cannot be found in science alone.

The failure of ecology to provide solutions to large scale environmental problems contributed to the development of environmentalism, an activity that is generally more socially, politically and value-based than scientifically based. However, in seeking scientific respectability, many environmentalists claim to be riding under the banner of ecology. At the same time, many ecologists and many disciplinary scientists, sensing the impotence of their science with respect 
to these issues, joined the ranks of the environmentalists. As a result, the distinction between ecology and environmentalism has become increasingly blurred in the minds of the public. It has become commonplace to talk about "ecologically-sound forest management" as though ecology can tell us what we should and should not do in forestry.

\section{The Contributions of Ecology, Environmentalism and Green Religion to Conservation and Sustainable Development}

Ecology - As the science that describes and seeks to understand and predict ecosystems and their components and processes, ecology has a vital role to play in the design of sustainable forest management systems and successful conservation strategies. All too often, conservation measures and resource management activities that ignore our current understanding of ecosystems fail to achieve their objectives. History is replete with examples of the failure of well-intentioned efforts to protect species and environments against mismanagement and exploitation because they were not based on an adequate understanding of ecology.

A sound understanding of ecology is one of the necessary foundations for conservation and sustainable development of resources. However, it is not a sufficient foundation on its own. Because ecology provides no understanding of the social values required from, and provided by, forests, and because it provides no basis for value-judgements, the science of ecology on its own cannot be the paradigm for conservation or sustainable development. We can only design "ecologically-sound management" or "ecologically-wise", activities based on prevailing social value systems.

Ecology is necessary for conservation and resource management, but it is not sufficient.

Green religion - Belief systems about forest ecosystems are an essential part of how humans have, and should, conduct their relationships with forests. The concepts of respect for the forest environment, of the spiritual and aesthetic values of forested ecosystems, and of ethical responsibility to pass on forest ecosystems to future generations without unacceptable loss of values at the landscape level are central to the design of sustainable forest management.

Green religion provides to society a set of ethical standards and moral responsibilities about our forests. This contribution parallels the contributions of the classical religions to human societies. Society would be impoverished without the ethical contributions of religions. However, there is ample evidence that belief systems, on their own, fail to provide a workable paradigm for the organization and conduct of human societies. Unfettered by secular considerations and scientifically based information, religion can become a rigid control system that, taken to extremes, can lead to totalitarian political control and fundamentalism.

The intolerance and violence that frequently accompanies the adoption of fundamental religious belief systems as the operational paradigm for a society stands as a warning that belief systems are, like the science of ecology, a necessary but not a sufficient basis for successful conservation and resource management.

Environmentalism - Defined as a system that integrates the inputs from the sciences, both biophysical and social, and "green" belief systems with the needs and aspirations of human societies, environmentalism is surely the paradigm that we need for sustainable resource development and conservation.

Environmentalism and forestry share the same origins: the desire to sustain a defined set of conditions and values in our forested landscapes. There may be a conflict over what balance of conditions and values should be sustained, but there can be no question that sustainability is the cornerstone of both activities. Unfortunately, forestry has often become confused in the public's mind with the unregulated exploitation of forests, with greed and wastefulness, and with environmental "damage", none of which should occur in a well managed, sustainable forestry endeavor. Equally unfortunate, environmentalism has become confused with green belief systems and ecology, neither of which constitute the central concept of environmentalism. The green religion movement has become synonymous in the minds of many people with the environmental movement, and it is assumed by many that ecology provides the guidelines for environmentalism.

As a result of these confusions, foresters are often portrayed as being anti-environmentalist, and environmentalists as being anti-forestry. The conflict between economic belief systems and green belief systems is used to imply that there is a fundamental conflict between forestry and environmentalism. This is incorrect, because economics, though it is of fundamental importance in forestry, should not be the sole consideration in forest management, and conversely economics is a vital part of successful environmentalism. Forestry should not be practiced solely according to green belief systems, but foresters should respect such systems and accept that they are one of many necessary inputs to their decision making. Similarly, forestry should not be guided solely by economic belief systems, although economic considerations will always constitute one of the important contributions to planning how forests are managed.

\section{Foresters as Environmentalists}

It is time to sort out the confusion between ecology, environmentalism and green religion and to recognize the unique contributions that each of these make to conservation and sustainable management of forests. Failure to do so will render the resolution of our forestryenvironmentalism conflicts akin to "bailing fog" (a New Brunswick expression): it is hard to see what you are achieving and little apparent progress is made.

It is time for foresters, environmentalists and green religion people to establish where they share common goals, where the differences lie, and how they can use the science of ecology to help to design more sustainable forest management.

It is time for foresters to accept that they should be the leaders in the forestry-related environmental movement, and to accept the responsibilities that this implies. This does not mean leaving behind economic, biophysical and social realities, and embracing uncritically all that green belief systems hold. Rather, it implies a respect for these belief systems and the adoption of values provided by these systems where these values will clearly assist in the achievement of sustainable forest management for a variety of different resource values.

None of this will be easy. But it couldn't be more difficult and unsatisfactory than continuing the status quo of confusion 
between the distinct and important contributions made to our quest for sustainability by ecology, environmentalism and green religion.

\section{Conclusions}

Forests offer diverse values to society, including timber, aesthetics, wildlife and biodiversity values. They must be managed to provide the balance of values at the landscape level that the prevailing society deems to be consistent with the basic concept of sustainable development: to satisfy the needs and aspirations of present generations of humans without compromising the ability of future generations to satisfy their needs and aspirations.

Management of forests to satisfy the requirements of sustainability will not be successful if based solely on the science of ecology, because this science cannot tell foresters what their goals should be. It will also fail if it is based solely on green religion, because this frequently ignores the ecological requirements of many of the living organisms in forest ecosystems, and the needs of the world's present 5.6 billion people, let alone the 12-16 billion that are expected within the next century.

Broadly defined environmentalism should be the basis for managing and conserving the world's forests. This management should be based on the ecology of these forests, should address the multiple values they provide, and should respect current ethical standards concerning the environment. The foresters performing this management should be dedicated environmentalists (in the broad sense). Unless the forestry profession becomes the leader in forest environmentalism, there is a significant risk that forestry in the future will be based largely on green religion.

\section{Frais d'adhésion 1992-1993}

Membre actif

Première et deuxième année suivant la graduation (graduation de 1991 et de 1992) $*(2.49 \$$ de T.P.S. inclus)

Nouveau membre pour une première année * $(2.49 \$$ de T.P.S. inclus $)$

Marié ou équivalent

Deuxième adhésion seulement $*(2.49 \$$ de T.P.S. inclus $)$

Tout autre membre actif $*(2.49 \$$ de T.P.S. inclus $)$

Autres catégories de membres

Membre à la retraite (afin d'obtenir le statut de membre à la retraite,

ce dernier doit être membre de l'Institut depuis quinze ans)

$*(2.49 \$$ de T.P.S. inclus)

Membre étudiant $*(1.31 \$$ de T.P.S. inclus $)$

Membre de soutien (membre de l'IFC/CIF)

Membre corporatif $*(4.98 \$$ de T.P.S. inclus $)$

Suite à une demande écrite, le conjoint d'un membre actif peut obtenir une réduction de ses frais d'adhésion en fonction d'un montant déterminé annuellement. Les membres conjoints sont membres d'une même section, demeurent ensemble en tant que conjoints et utilisent la même adresse postale.

L'année budgétaire de l'Institut débute le ler juillet pour se terminer le 30 juin. Les demandes d'adhésion effectuées après le ler janvier 1992, seront facturées à la moitié des frais d'adhésion de l'Institut pour l'année en cours. Aucun frais d'adhésion ne sera facturé au membre soumettant une demande après le ler avril pour la durée de l'année en cours.

Le frais de section s'additionnent à ce montant et varient de $5.00 \$$ à $30.00 \$$ pour l'année budgetaire de l'Institut.

*N.B.: La portion des frais d'adhésion couvrant les frais du Forestry Chronicle est assujettie à la T.P.S. Pour les fins de la taxe, ce coût est calculé sur une base de 38.00 \$ et correspond à 2.49 \$ de T.P.S. (sauf pour le taux étudiant de 20.00 \$, soit 1.31 \$ de T.P.S.) 